\title{
Urban Expansion and Its Effect on Agricultural Technology Adoption of Smallholder Peri-Urban Farmers in Tigray Region, Ethiopia
}

\author{
Shishay Kahsay Weldearegay ${ }^{1 *}$, Mesay Mulugeta Tefera $^{2}$ and Solomon Tsehay Feleke ${ }^{2}$ \\ ${ }^{1}$ Department of Animal Sciences, Aksum University, Tigray, Ethiopia; ${ }^{2}$ Center for Food Security Studies, \\ Addis Ababa University, Addis Ababa, Ethiopia \\ ${ }^{*}$ Corresponding author: shishay.k2002@gmail.com
}

\begin{abstract}
In the rapidly growing world, where farming land is shrinking due to horizontal urban expansion and development-induced projects, agricultural productivity should grow by $70 \%$ to meet food needs. Spatial urban expansion in developing countries, not exceptional to Ethiopia, puts immense pressure by taking peri-urban fertile agricultural land for the purpose of development. This paper examines whether urban expansion increases or decreases the agricultural technology adoption capacity of smallholder peri-urban farmers. Households were clustered into displaced and non-displaced, and data were collected from 341 households, 101 of whom were displaced and 240 households were non-displaced. Descriptive statistics and econometric model were employed to explore the role of urban expansion in technology adoption of smallholder peri-urban farmers. The multivariate probit result shows that urban expansion decreases the tendency of displaced smallholder peri-urban farmers to participate in irrigation and adoption of a generator but urban expansion does not increase or decrease displaced households' tendency to adopt beehive and practice row sawing. Generally, urban expansion decreases the affinity of smallholder peri-urban farmers to adopt agricultural technologies. Therefore, policymakers, particularly the Bureau of Agriculture should intensively work and train displaced smallholder periurban farmers on the benefit of agricultural technologies to improve agricultural productivity and use the remaining plot of farmland sustainably. Besides strong monitoring and follow-up are required to avert the negative ramifications of development-induced displacement.
\end{abstract}

Keywords: agricultural technology; displaced households; farm household; multivariate probit

Cite this as: Weldearegay, S. K., Tefera, M. M., \& Feleke, S. T. (2021). Urban Expansion and Its Effect on Agricultural Technology Adoption of Smallholder Peri-Urban Farmers in Tigray Region, Ethiopia. Caraka Tani: Journal of Sustainable Agriculture, 36(2), 365-378. doi: http://dx.doi.org/10.20961/carakatani.v36i2.53505

\section{INTRODUCTION}

Enhancing agricultural productivity is a basis and precondition to transform agriculture in developing countries (de Janvry et al., 2016). To do so, applying relevant agricultural technologies ${ }^{1}$ to modernize subsistence production is informed to be a genuine approach to meet the food needs of the ever-growing human population (Abdullahi et al., 2015). In several developing countries, not exceptional to Ethiopia, subsistence agriculture has a significant contribution to the national economic growth applying their natural wisdom (CIMMYT, 1993). Therefore, an achievable shift could be made on the agricultural productivity of smallholder farmers through disseminating agricultural technology (de Janvry et al., 2016). Investing in agricultural technologies reduces

\footnotetext{
${ }^{*}$ Received for publication July 20, 2021

Accepted after corrections August 18, 2021

${ }^{1}$ Agricultural technology refers to physical objects like high-yielding seeds, fertilizers, herbicides, pesticides and farming systems to improve agricultural productivity
} 
poverty and improves food security through boosting food production and supplying surplus products to the market (Gill, 2002; Mekonnen, 2009). In sum, in areas where farming land is converted to residential areas, modernizing agriculture to increase productivity per unit area and profitability is unquestionable to tackle poverty in rural households (World Bank, 2008).

Horizontal urban expansion is seen as one of the development challenges of African economies. Hence, the recent development pathways including Sustainable Development Goals-2030 (Goal 11) have explicitly considered sustainable cities and communities as one of the future development agendas of the developing countries (United Nations Development Programme, 2015). To realize this big goal, creating green public spaces, and improving urban planning and management in participatory and inclusive ways need to be done. Boserup's theory and other theories describe the long-term process of land use intensifications driven by population pressure and land scarcity, which endogenously induces technological and institutional innovations to raise agricultural output from a given land. Under the pressure of population growth, a shift from extensive to relatively intensive systems of land use has been witnessed in almost every part of the world (Boserup and Chambers, 1965). As people shift out from agriculture to more remunerative activities off the farm and outside the rural areas, a positive virtuous economic dynamic is set in motion, with new opportunities being generated, by attracting poor rural workers who gain directly and by positively affecting the rural areas indirectly, through remittances and increased demand for their goods, fostering economic growth and reducing poverty (Christiaensen et al., 2013).

Empirical studies of rural to urban migration focus largely on cash remittances from urban to rural areas, with migration generally considered to have a positive effect on rural household incomes. Studies on the direct linkages between cash remittances and farm investments are less common. Tiffen (2003) notes the importance of cash remittances for making investments in improved agricultural technology among smallholders in West Africa. The share of remittances in rural cash incomes is generally small in Sub-Saharan Africa, however, and tied to historical patterns of mobility. Cash remittances, therefore, do not constitute a likely source of capital for the general upgrading of smallholder agricultural technology. Unlikely, case studies show farmers have invested and adopted new agricultural technologies but the transition to an urbanized economy has been hindered by poor policies (Tiffen, 2003).

The achievement of the green revolution in Asia gave a lesson to African countries to utilize and adopt modern agricultural inputs particularly improved crop varieties to improve agricultural productivity (Awotide et al., 2016). A study conducted in Shanghai shows periurban agricultural land converted to residential and other development works as a result high technology like hydroponic, indoor horticulture and vertical agriculture is widely practiced around the cities (Hosseinifarhangi et al., 2019). Gwan and Kimengsi (2020) confirm that urban expansion forces farmers to practice agricultural intensification and adopt high-value crops as coping strategies in Bamenda City, Cameroon. Another study conducted in Ethiopia indicates displaced farmers get better access to improved dairy farms, animal fodder and poultry farming (Mengistu, 2016). Urban development increases off-farm employments, which will enhance the opportunity costs of more intensive farming (Uchida et al., 2009). Besides, urban expansion creates a favorable condition for the development of peri-urban agriculture to use lands which are not effectively used for constructions (Feola et al., 2020). Therefore, advancing urban agriculture has an indispensable role to effectively utilize limited resources and to address the food needs of growing city populations, and avert the negative environmental and economic consequences of urban expansion thereby attaining food and nutrition security (Feola et al., 2020). In addition to providing fresh and healthy food, it is also essential in safeguarding cultural heritage and agro-biodiversity (Langemeyer et al., 2021). Despite the positive role of peri-urban agriculture, farmers were concerned about legal recognition and inclusion of their agricultural land in the planning process, and many feared being dispossessed of their farmland (Feola et al., 2020). Hence, "the spatially explicit urban metabolism (e.g. energy, water, nutrients), as well as ecosystem services need to be stronger and jointly considered in land-use decision-making" (Langemeyer et al., 2021). 
In developing countries, limited access to credit, inaccessible information, small farm plot, low educational performance, lack of suitable farm equipment, lack of accessory materials and poor infrastructure facilities are a few among the factors that hinder agricultural technology adoption (Meinzen-dick et al., 2004). A study conducted in China reveals that farmers' experience, training and positive attitude to agricultural technology adoption are limiting factors to adopt agricultural packages ( $\mathrm{Li}$ et al., 2020). A panel data collected from 25 counties in Africa reports policy-related tools like access to information, access to credit, and wealthrelated factors like land size, livestock possession and off farm-income are positively related to the adoption of agricultural technologies (Arslan et al., 2020).

In Ethiopia, various improved agricultural technologies have been disseminated although the majority of them are location specific (Admassie and Ayele, 2010). As stated in Muzari et al. (2012) asset ownership, income, institutions, knowledge on technology, labor and the innovative nature of the farmers are key factors affecting agricultural technology adoption of smallholder farmers. The adoption of agricultural technologies was mainly affected by demographic factors, socio-economic factors and institutional factors (Melisse, 2018). In general, studies have been done on the impact of urban expansion on poverty, urban expansion and its effect on traditional agriculture, and the impact of urban expansion on the livelihood of farmers (Egidi et al., 2020; Rustiadi et al., 2021; Weldearegay et al., 2021). Besides, much has been done on the determinants of agricultural technology adoption on agricultural productivity. However, the effect of urban expansion on smallholder peri-urban farmers' agricultural technology adoption was hardly studied. Therefore, this study investigates whether urban expansion increases or decreases agricultural technology adoption capacity of smallholder peri-urban farmers.

\section{MATERIALS AND METHOD}

\section{Physical description of the study area}

Laelay Maichew Woreda is part of the central zone Tigray Regional State of Ethiopia. It is located 1,043 km away from Addis Ababa and $245 \mathrm{~km}$ northwest of Mekelle, the capital city of
Tigray. It is situated on the main road of Adwa and Shire. It is bordered by Merebleke to the north, Adwa to the east, Werileke and Nader Adiet to the south and Tahtay Maichew to the west. The region is situated at a latitude of $14^{0} 6^{\prime} 0^{\prime \prime}$ to $14^{0} 9^{\prime} 0^{\prime \prime} \mathrm{N}$ and longitude of $38^{\circ} 42^{\prime} 0^{\prime \prime}$ to $38^{0} 45^{\prime} 0 " \mathrm{E}$ (Figure 1). The agroecology of the Woreda is characterized as Woinadega and Kolla. Woinadega is the dominant agroecology of the Woreda which is suitable for growing tef, sorghum, barley, wheat, beans, millet and maize. The topography of the area is classified as rugged and gentle slope arable land. The elevation of the area varies from 1375 to 2450 meters above sea level. The climatic condition of the area is comfortable and overcast during the rainy season, and warm and partly cloudy during the dry season. The temperature varies from $18^{\circ} \mathrm{C}$ to $25^{\circ} \mathrm{C}$ with an average annual rainfall of $937.4 \mathrm{~mm}$ (National Metrological Agency of Ethiopia, 2019). The livelihood of the people mainly depends on subsistence agriculture and petty trading, daily labor, mining and other sources of income are secondary sources of income of the Woreda.

\section{Research design}

Mixed-methods research was applied, where the majority of the data are generated from quantitative data and underpinned by qualitative data to deeply support and elaborate statistical results (Creswell et al., 2003). This cross-sectional study demands a combination of quantitative and qualitative data to explore the study deeply.

\section{Sampling techniques and sample size determination}

A multi-stage sampling technique was applied to select the study area, tabias and epitome of the target group. The study area was purposively identified referring to its rapid urban expansion demographically and spatially only towards the prime agricultural land. Besides, it is a tourist site, so, private sectors and government bodies are demanding more land for housing development every year. Secondly, urban dwellers in historical sites are relocated to the periphery of the farmers' prime farming land. Lastly, compared to another part of Tigray, the area where urban expansion currently encroaches is fertile agricultural land known for its tef production.

The population and unit of analysis of the study are households in the peri-urban tabias 
where their main livelihood depends on agriculture and has common boundaries with Axum Town. Hence, Hatsebo and Modegue were selected purposively because the town is expanding only to these two tabias. Then, households are classified into partially displaced/dispossessed and non-displaced to see the effects and the associated impact of displacement. Households are also stratified into male and female-headed households because there are many female-headed households in the study area. Finally, simple random sampling was used to take representatives of non-displaced households from each tabia.

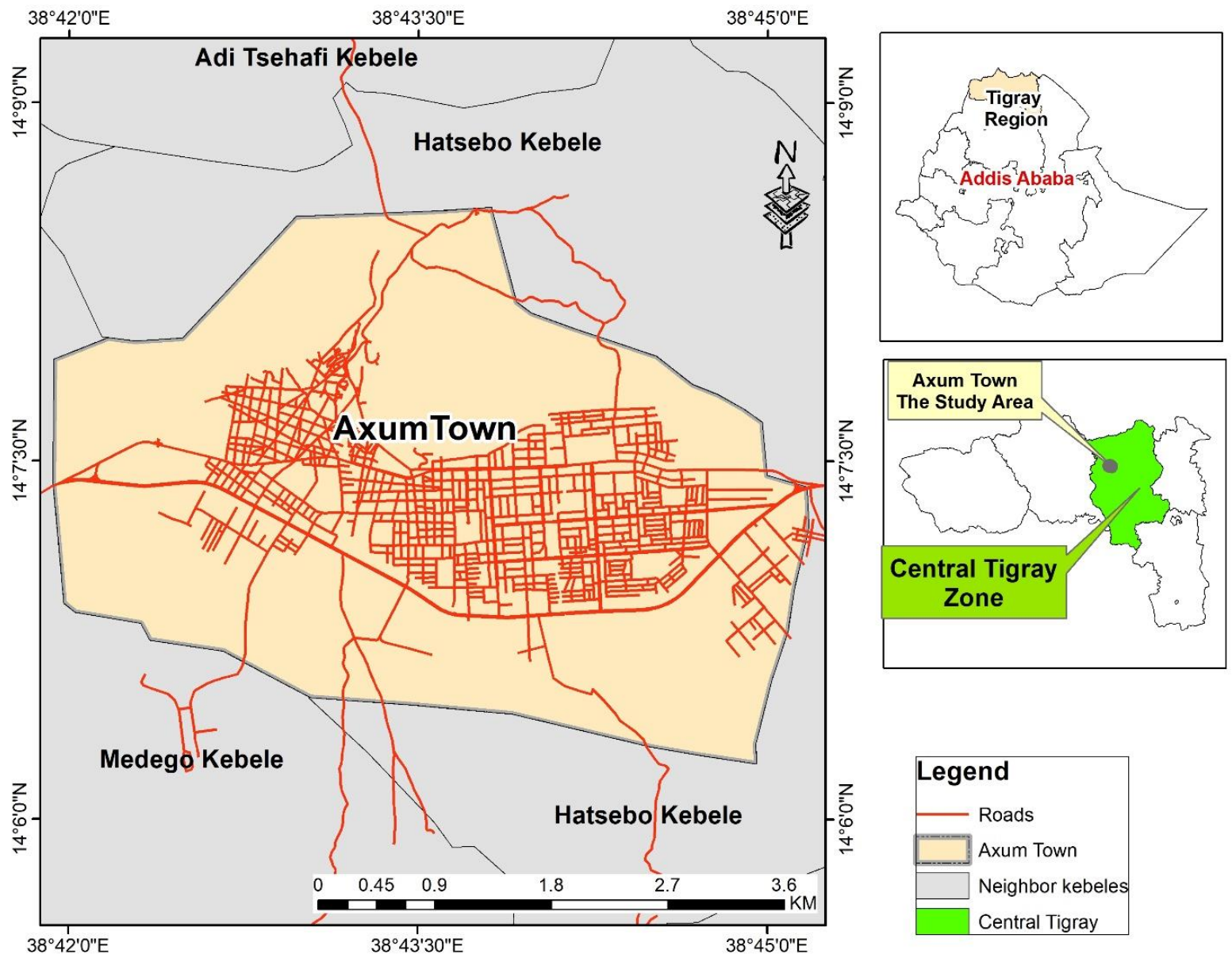

Figure 1. Location map of the study area, Axum Town, Tigray Region

The sample size determination formula developed by Chochran (1977) was used to estimate the sample size of the finite population and is presented as follows;

1. If the population is infinite, the formula is;

$$
\mathrm{n}_{0}=\frac{\mathrm{z}^{2} \mathrm{pq}}{\mathrm{e}^{2}}
$$

$\mathrm{n}_{0}$ is a sample size, $\mathrm{z}$ is the selected value of desired confidence level, $p$ is the estimated proportion of an attribute that is present in the population, $q=1-p$, and e, the desired level of precision.

2. If the population is finite the sample size is estimated as follows;

$$
\mathrm{n}=\frac{\mathrm{n}_{0}}{1+\frac{\left(\mathrm{n}_{0}-1\right)}{\mathrm{N}}}
$$

$\mathrm{n}_{0}$, is sample size derived above, $\mathrm{N}$ is population size. Therefore, a total of 341 households were taken. Since households are stratified into male and female-headed households, a proportional allocation method was employed to get representative households of the tabia. The formula is, $\mathrm{n}_{\mathrm{i}=\mathrm{n}} \frac{\mathrm{N}_{\mathrm{i}}}{\mathrm{N}}$, where $\mathrm{n}=$ sample size, $\mathrm{N}_{\mathrm{i}}=$ population size of the $\mathrm{i}^{\text {th }}$ strata and $\mathrm{N}$ population size, $\mathrm{i}=1,2,3$. Finally, 101 displaced and 240 non-displaced households were taken (Table 1). The reason 
behind taking 101 displaced farming households was that there were 101 displaced households, whose livelihood mainly depends on agriculture. The rest of the displaced farm households are engaged in other income source activities. This drove the researcher to select only 101 displaced farming households and to examine the effect of urban expansion on agricultural technology adoption of smallholder peri-urban farmers.

Table 1. Household size and sample size

\begin{tabular}{|c|c|c|c|c|c|c|c|c|}
\hline \multirow{3}{*}{ Tabias } & \multicolumn{3}{|c|}{ Population size } & \multicolumn{4}{|c|}{ Sample households } & \multirow{3}{*}{ Total } \\
\hline & \multirow{2}{*}{ Male } & \multirow{2}{*}{ Female } & \multirow{2}{*}{ Total } & \multicolumn{2}{|c|}{ Displaced } & \multicolumn{2}{|c|}{ Non-displaced } & \\
\hline & & & & Male & Female & Male & Female & \\
\hline Hatsebo & 1,183 & 491 & 1,674 & 40 & 16 & 93 & 39 & 188 \\
\hline Medogue & 995 & 368 & 1,363 & 33 & 12 & 79 & 29 & 153 \\
\hline Total & 2,178 & 859 & 3,037 & & & & & 341 \\
\hline
\end{tabular}

Source: Computed from Laelay Maichew (WOARD, 2019)

\section{Techniques of data collection}

To meet the objective of the study, quantitative and qualitative data were gathered. Primary quantitative data were collected using a structured survey questionnaire through a personal interview. Likewise, primary qualitative data were generated from focus group discussion, key-informant interviews and participant observations. Meanwhile, secondary data were collected from published and unpublished documents, articles, and websites, particularly, demographic, socioeconomic, climate data, etc.

\section{Model specification multivariate probit model}

A multivariate probit model was applied to examine the effect of urban expansion on agricultural technology adoption of periurban smallholder farmers. The agricultural technologies selected in the study area include participation in irrigation, generator, modern hive and row sawing. Despite chemical fertilizers, pesticides and selected tef variety, both the displaced and non-displaced households have the problem of introducing these agricultural technologies. Therefore, participation in irrigation, generator, modern hive and row sawing were selected to see the effect of urban expansion on agricultural technology adoption of peri-urban farmers using a multivariate probit model. This estimates several correlated binary outcomes together. We began by first defining the notation consistent with that used in the introduction. Let $\mathrm{I}_{\mathrm{j}}^{\mathrm{O}}$ denote the underlying latent response associated with the $\mathrm{j}^{\text {th }}$ type of claim, for $\mathrm{j}=1 \ldots \mathrm{J}$ and $\mathrm{I}_{\mathrm{j}}$ denote the binary response outcome associated with the same type. Using the indicator function, $I_{j}$ is equal to one if there is a claim with respect to the $\mathrm{j}^{\text {th }}$ type and zero otherwise. Therefore, our MVP may be specified as a linear combination of deterministic and stochastic components as follows:

$$
\begin{array}{ll}
\mathrm{I}_{1}^{*}=\mathrm{x} \beta_{1}+\epsilon_{1}, & \text { for } \mathrm{I}_{1}=\Pi_{\left\{\mathrm{I}_{1}^{*}>0\right\}} \\
\mathrm{I}_{1}^{*}=\mathrm{x} \beta_{2}+\epsilon_{2}, & \text { for } \mathrm{I}_{2}=\Pi_{\left\{\mathrm{I}_{2}^{*}>0\right\}} \\
\mathrm{I}_{\mathrm{J}}^{\mathrm{o}}=\mathrm{x}^{\prime} \beta_{\mathrm{J}}+\epsilon_{\mathrm{J}}, & \text { for } \mathrm{I}_{\mathrm{J}}=\Pi_{\left\{\mathrm{I}_{\mathrm{J}}^{\mathrm{o}}>0\right\}}
\end{array}
$$

Where, $\mathrm{x}=\left(1, x_{1} \ldots \ldots \ldots x_{p}\right)$ is a vector of $\mathrm{p}$ covariates which do not differ for each claimtype (the deterministic component) and $\beta_{j}=$ $\left(\beta_{j 0}, \beta_{j 1} \ldots \ldots \ldots \beta_{j p}\right)^{\prime}$ is a corresponding vector of parameters, including an intercept, which we seek to estimate. Note that the observation subscript $\mathrm{i}$ has been suppressed for notational convenience. The stochastic component, $\epsilon_{J}$, may be thought of as consisting of those unobservable factors which explain the marginal probability of making a type $\mathrm{j}$ claim. Each $\epsilon_{J}$ is drawn from a $\mathrm{J}$-variate normal distribution with zero conditional mean and variance normalized to unity (for reasons of parameter identifiability), where $\epsilon \sim \mathrm{N}(0, \Sigma)$, and the covariance matrix $\Sigma$ is given by:

$$
\sum=\left[\begin{array}{c}
1 \ldots p_{12} \ldots p_{j} \\
p_{21} \ldots 1 \ldots p_{2 j} \\
\cdot \\
p_{J 1} \ldots \\
p_{J 2} \ldots 1
\end{array}\right]
$$

Note that in this formulation of the MVP model, we can derive marginal probabilities directly. For instance, the marginal probability of observing the $j^{4}$ type of claim can be expressed as: 


$$
\operatorname{pr}\left(\mathrm{I}_{\mathrm{j}}=1\right)=\phi\left(\mathrm{x}^{\prime} \beta_{\mathrm{i}}\right), \text { for } \mathrm{J}=1, \ldots, \mathrm{J}
$$

Where $\phi(\cdot)$ denotes the cumulative distribution function of the standard normal. Moreover, the joint probability of observing all possible types of claim comes from a J-variate standard normal distribution (Young et al., 2009).

$$
\operatorname{pr}\left(I_{1}=1, \ldots, J\right)=\phi_{J}\left(x^{\prime} \beta_{1}, \ldots, x^{\prime} \beta_{J} ; \Sigma\right)
$$

where $\sum$ is the covariance matrix.

\begin{tabular}{|c|c|c|c|}
\hline Variables & Description of variables & Expected sign & Types of variable \\
\hline $\begin{array}{l}\text { Irrigation, beehive, } \\
\text { generator, row sawing }\end{array}$ & & & $\begin{array}{l}\text { Dependent } \\
\text { variables }\end{array}$ \\
\hline AccessCrdt & $\begin{array}{l}\text { Access to credit (dummy) } 0=\text { no, } \\
1=\text { yes }\end{array}$ & + & $\begin{array}{l}\text { Independent } \\
\text { variable }\end{array}$ \\
\hline AccessEx & $\begin{array}{l}\text { Access to extension service } \\
\text { (dummy) } 0=\text { no, } 1=\text { yes }\end{array}$ & + & $\begin{array}{l}\text { Independent } \\
\text { variable }\end{array}$ \\
\hline AgeHH & $\begin{array}{l}\text { Age of household head in number } \\
\text { (continuous) }\end{array}$ & $+/-$ & $\begin{array}{l}\text { Independent } \\
\text { variable }\end{array}$ \\
\hline EDHH & $\begin{array}{l}\text { Educational level of household } \\
\text { head in number (continuous) }\end{array}$ & + & $\begin{array}{l}\text { Independent } \\
\text { variable }\end{array}$ \\
\hline Farmingyear & $\begin{array}{l}\text { Farming experience in years } \\
\text { (continuous) }\end{array}$ & + & $\begin{array}{l}\text { Independent } \\
\text { variable }\end{array}$ \\
\hline Fsize & $\begin{array}{l}\text { Family size in number } \\
\text { (continuous) }\end{array}$ & $+/-$ & $\begin{array}{l}\text { Independent } \\
\text { variable }\end{array}$ \\
\hline SexHH & $\begin{array}{l}\text { Sex of household head (dummy) } \\
0=\text { female, } 1=\text { Male }\end{array}$ & +- & $\begin{array}{l}\text { Independent } \\
\text { variable }\end{array}$ \\
\hline Irrland & $\begin{array}{l}\text { Irrigated land in hectare } \\
\text { (continuous) }\end{array}$ & + & $\begin{array}{l}\text { Independent } \\
\text { variable }\end{array}$ \\
\hline Landsize & Land size in hectare (continuous) & + & $\begin{array}{l}\text { Independent } \\
\text { variable }\end{array}$ \\
\hline Marketdis & $\begin{array}{l}\text { Market distance in kilometer } \\
\text { (continuous) }\end{array}$ & - & $\begin{array}{l}\text { Independent } \\
\text { variable }\end{array}$ \\
\hline Nfarmincome & $\begin{array}{l}\text { Non-farm income in birr } \\
\text { (continuous) }\end{array}$ & + & $\begin{array}{l}\text { Independent } \\
\text { variable }\end{array}$ \\
\hline Remittance & Remittance in birr (continuous) & + & $\begin{array}{l}\text { Independent } \\
\text { variable }\end{array}$ \\
\hline TLU & $\begin{array}{l}\text { Tropical livestock unit in number } \\
\text { (continuous) }\end{array}$ & + & $\begin{array}{l}\text { Independent } \\
\text { variable }\end{array}$ \\
\hline Treatment & $\begin{array}{l}\text { Treatment (dummy) } 0=\text { non- } \\
\text { displaced, } 1=\text { displaced }\end{array}$ & - & $\begin{array}{l}\text { Independent } \\
\text { variable }\end{array}$ \\
\hline
\end{tabular}

Table 2. Variables affecting agricultural technology adoption used in the multivariate probit model

Source: Jebesa (2017), Happy et al. (2019) and Weldearegay et al. (2021)

\section{RESULTS AND DISCUSSION}

\section{Selecting agricultural technologies}

The assumption made in this study is that displaced and non-displaced households' tendencies to adopt agricultural packages vary. Achieving this hypothesis demands a selection of relevant agricultural technologies practiced and disseminated by the Bureau of Agriculture in the region. As presented in Table 3, out of the different technologies used in the study area, four agricultural technologies were selected. Due to its long-years extension works, both displaced and non-displaced households do not have any problem of adopting other agricultural technologies and practices like fertilizer, modern seed, animal fodder and water harvesting technologies, etc. Therefore, to evaluate agricultural adoption difference between displaced and non-displaced households, row sawing, modern hive, generator and practicing irrigation were chosen as agricultural packages. As previously stated, adopting fertilizer, animal fodder, modern seed and 
water harvesting technologies is not such a problem for both displaced and nondisplaced farmers. Therefore, including such variables to see variation between displaced and non-displaced households does not give sense and consequently, those agricultural technologies were excluded from the multivariate probit model.

Table 3. Frequency distribution of selected agricultural technology adoption

\begin{tabular}{llrrr}
\hline \multicolumn{1}{c}{ Type of technology } & \multicolumn{1}{c}{ Treatment } & Adopter & Non-adopter & Total \\
\hline Row sawing & Control (non-displaced) & 64 & 176 & 240 \\
& Treated (displaced) & 30 & 71 & 101 \\
\cline { 2 - 5 } & Total & & & 341 \\
\hline Modern hive & Control (non-displaced) & 11 & 229 & 240 \\
& Treated (displaced) & 9 & 92 & 101 \\
\cline { 2 - 5 } & Total & 66 & 174 & 240 \\
\hline Irrigation & Control (non-displaced) & 20 & 81 & 101 \\
& Treated (displaced) & & & 341 \\
\cline { 2 - 5 } & Total (non-displaced) & 28 & 212 & 240 \\
\hline Generators & Control (nisplaced) & 5 & 96 & 101 \\
& Treated (dis) & & & 341 \\
\cline { 2 - 5 } & Total & & &
\end{tabular}

Source: Computed from own survey data (2019)

\section{Effects urban expansion on agricultural technology adoption}

Theoretical and empirical literature describe that adoption of agricultural packages require adequate farmland. If they do not have land, they are not willing to invest in agricultural technologies. The result underpins the apriori hypothesis. Displaced households has a negative statistically significant effect on adopting a generator and participating in irrigation (Table 4 and 5). This implies that displaced households are less likely to purchase a generator and actively participate in irrigation activities. A unit increase in the number of displaced households decreases the probability of households engaged in irrigation and purchasing generators by $53.7 \%$ and $96.7 \%$, respectively, keeping other variables unchanged. Displaced households have a small plot of land and a lower educational level. Hence, displaced smallholder farmers are not interested in engaging in irrigation and buying a generator to produce food crops using irrigation. Rather, they search for other non-farm incomegenerating activities to meet the food needs of the households. Surprisingly, adopting a modern hive is identified to have a negative neutral relationship with displaced households. Whereas row sawing is positively and not significantly correlated to displaced households.

An inverse relationship is spotted between the age of the household head and participation in irrigation. One year increase in the age of household head decreases the probability of households participating in irrigation by $6.2 \%$, keeping other factors constant. The result reveals that younger households participate better in irrigation than older household heads. Irrigation is labor-intensive and demands a variety of agricultural packages. Therefore, young farmers comparably have enough physical fitness to effectively manage irrigation. A consistent result was found by Chuchird et al. (2017), Sharaunga and Mudhara (2018), Deksisa and Bayissa (2020). They report that as the household head age increases, the tendency to participate in irrigation decreases. A similar result was also found by Sisay (2018). He explains that elders are reluctant, not risk-takers and incapable of working much time.

Households with larger family sizes are more likely to participate in irrigation schemes. Compared to other agricultural activities, irrigation demands much labor. A unit increase in the family size of households increases the likelihood of participating in irrigation by $10.9 \%$, keeping other variables constant. Households with large family sizes are more actively engaged in irrigation than households with small family sizes. This finding agrees with Deksisa and Bayissa (2020). They suggest that household who has large size engaged in the agricultural labor force has better chance to use irrigation water. 
Farming experience is another covariate that has a positive statistically significant effect on households participating in irrigation. Experienced farmers have a deep understanding of agronomic practices and the know-how to allocate available resources. Therefore, as farmers' experience increases, the tendency of households' participation in irrigation increases in the study area. A unit increase in the farming experience of household head increases the likelihood of engaging in irrigation by $5.9 \%$, keeping other variables constant. This contradicts Regassa (2015) who states that the probability of changing means of livelihood to other non-farm activities is higher among experienced farmers.

Households with a large number of livestock possession are intensively involved in irrigation than households with a small number of livestock. Increasing TLU by one unit increases households' participation in irrigation by $14.9 \%$, keeping other factors fixed. In rural areas, livestock is an important asset. Majority of farmers with a large number of livestock participate in irrigation to produce green animal feeds to increase the productivity of milk and beef. This result is in line with Urgessa et al. (2020). Households with large livestock owners have better access to finance by selling livestock, which helps them invest in irrigation aggressively.

Tigray region is known for its diversified colors and qualities of honey. Compared to other livestock farming, honey bee production needs a small plot of land. This motivates farmers to engage in honey bee production. The multivariate probit estimation result shows that the household head sex is positively and significantly correlated with the adoption of modern hive. A unit increase in the number of male-headed households increases the probability of adopting modern beehives by $74.9 \%$, keeping other factors constant. This implies male-headed households are more likely to adopt modern hives than female-headed households. Femaleheaded households are swamped with caring for and preparing foods. This competes their time and fails to properly manage honey bee production. Besides, honey bee is aggressive so this puts pressure on female-headed households and limits their participation. This result agrees with Chemwok et al. (2016). They justify that female-headed households are less likely to participate in beekeeping compared to male- headed households. Contrarily, Fetenssa (2018) reports a negative and not significant correlation with the sex of household heads.

Education improves technology adoption of farmers and is a key to transform the livelihood of households. Increasing the educational level of households enhances the tendency to invest in the modern hive. Households with higher educational levels have a better capacity to adopt modern hive than households with lower educational levels. A unit increase in the educational level of the household heads increases the probability of adopting modern beehives by $6.5 \%$, keeping other variables unchanged. Theoretical and empirical literature suggests education helps farmers manage agronomic practices scientifically and adopt relevant agricultural packages to improve productivity. This result is parallel with the works of Abebe et al. (2008) and Bekuma (2018). They explain that exposure to education is generally supposed to increase a farmer's ability to obtain, process and use information relevant to the adoption of improved agricultural technologies.

Remittance plays important role in solving liquidity problems and supplements agricultural production in Ethiopia. It is expected result that remittance improves the adoption of the modern beehive. Households who get higher remittances have a higher tendency to purchase modern beehives than households who get lower remittances. A unit increase in the amount of birr collected from remittance increases the likelihood of adopting modern beehive by $0.1 \%$, keeping other variables constant. It is important to note that modern agricultural technologies solicit a higher budget. Therefore, money generated from remittance increases the adoption of modern beehive. This agrees with the finding of Happy et al. (2019) who states remittance plays a great role to adopt and use agricultural technology in the farm household.

Livestock possession enhances modern beehive adoption. This meets the apriori hypothesis where increasing livestock possession ascends the adoption of modern agricultural packages. The result reveals that households with larger TLU have superior capacity to purchase modern beehives than households with smaller TLU. A unit increase in TLU increases the probability of households adopting 
modern beehives by $18.8 \%$, keeping other factors constant. As stated above, livestock possession is an important community-based wealthy assessment. Therefore, farmers with large livestock possession are considered wealthier and actively participate in honey production. This finding agrees with Jebesa (2017). However, another study conducted by Fetenssa (2018) reports a negative and insignificant correlation.

Generator is among the irrigation technologies disseminated to enhance irrigation scheme productivity. Adopting generator is positively and significantly correlated with sex of household head. Male-headed households have a better affinity to purchase generators than female-headed households. A unit increase in the number of male-headed households increases the probability of households purchasing a generator by $14.6 \%$, keeping other variables constant. This is because in Ethiopia, female farmers are poor and poorly participate in non-farm activities to generate additional income. Besides, generators demand physical fitness to operate. This finding is in line with the work of Getacher et al. (2013). They justify that liquidity is a major constraint for adoption and as a result, female-headed households are often poorer and have less affinity to adopt a generator.

Surprisingly, non-farm income is negatively and significantly correlated with the adoption of a generator. Increasing the amount of money generated from non-farm income reduces the propensity of farmers to purchase generator and engage in irrigation in the study area. A unit increase in non-farm income decreases the probability of households purchasing generator by $0.1 \%$, keeping other variables constant. It is because the amount of income might be insignificant to purchase generators or farmers get better non-farm income to shift their livelihood to non-farm activities and involve in petty trading and other activities. TLU has a positive correlation and is significantly associated with adopting generators. As repeatedly stated above, increasing livestock possession enhances the purchasing power of farmers. This contradicts Happy et al. (2019) research conducted in Bangladesh.

In Ethiopia, agricultural extension workers are assigned up to kushet and tabia level by Bureau of Agriculture and limited achievements are recognized compared to years spent and experts deployed. However, the result confirms that access to extension service is positively and significantly correlated with adopting a generator. Households who get access to extension services increase the purchasing power of generators compared to those who do not get extension services. A unit increase in access to extension increases the probability of households in purchasing generators by $53.7 \%$, keeping other variables constant. The possible justification is that they get better awareness on the advantage of utilizing agricultural technologies. This result is consistent with Adeoti (2009), who states that households who get frequent extension services are better at introducing irrigation inputs.

Lastly, the recently introduced row sawing is discussed. Age of household head is inversely correlated with row sawing of tef. A unit increase in the age of the household head decreases the probability of tef row sawing by 3.3\%, keeping other factors constant. Elder households are less likely to practice tef row sawing than younger households. The possible explanation is that row sawing is labor-intensive compared to conventional sawing. Therefore, younger farmers are actively practicing row sawing even younger farmers engage in non-farm incomegenerating activities. This income helps them hire daily laborers. This result is in line with the finding of Abebe et al. (2008). They clarify that elders do not have an interest in row sawing because it is laborious. However, another study conducted by Tamirat (2020) finds a negative and neutral correlation.

Agricultural practice requires experience spent in farming. Farming experience is positively and significantly associated with row sawing. A unit increase in farming experience results in increasing the probability of households' row sawing by $4.1 \%$, keeping other factors constant. Farmers with higher years of farming experience are better in row sawing than farmers with fewer years of farming experience in the study area. Access to credit solves money liquidity of farmers to adopt agricultural packages for short time. Access to credit is positively and significantly associated with tef row sawing in the study area. A unit increase in the amount of credit increases the likelihood of households' tef row sawing by 50.5\%, keeping other variables constant. Households who get loans from the financial institution are better in 
row sawing compared to those who do not get a loan. Row sawing demands higher labor compared to conventional sawing so getting a loan helps farmers hire laborers to implement row sawing.

Lastly, the rho (correlation) shows that except for participating in irrigation and adopting generators, there is no correlation among the technological packages used. This shows that participating in irrigation and purchasing generators are complementary. Therefore, these two technologies go simultaneously. Whereas, the other technologies can adopt separately they had no complementary relationship.

Table 4. Multivariate probit result

\begin{tabular}{lcccccccc}
\hline \multirow{2}{*}{ Covariates } & \multicolumn{2}{c}{ Irrigation status } & \multicolumn{3}{c}{ Modern hive adoption } & \multicolumn{2}{c}{ Generator } & \multicolumn{2}{c}{ Row sewing } \\
\cline { 2 - 9 } & Coef. & Std. Err. & Coef. & Std. Err. & Coef. & Std. Err. & Coef. & Std. Err. \\
\hline AccessCrdt & -0.025 & 0.257 & 0.192 & 0.327 & 0.063 & 0.313 & $0.505^{* *}$ & 0.236 \\
AccessEx & 0.189 & 0.194 & 0.335 & 0.307 & $0.537^{* *}$ & 0.234 & -0.236 & 0.196 \\
AgeHH & $-0.062^{* * *}$ & 0.022 & 0.062 & 0.041 & -0.056 & 0.054 & $-0.033^{*}$ & 0.018 \\
EDHH & -0.009 & 0.029 & $0.064^{*}$ & 0.035 & 0.015 & 0.035 & -0.005 & 0.026 \\
Farmingyear & $0.059^{* * *}$ & 0.022 & -0.053 & 0.039 & 0.053 & 0.052 & $0.041^{* *}$ & 0.017 \\
Fsize & $0.109^{* *}$ & 0.049 & 0.129 & 0.087 & 0.047 & 0.059 & -0.004 & 0.048 \\
lsize & 0.190 & 0.363 & -0.786 & 0.534 & 0.363 & 0.415 & -0.226 & 0.334 \\
MarketDis & -0.062 & 0.060 & -0.053 & 0.108 & -0.108 & 0.077 & 0.042 & 0.057 \\
Nfarmincome & -0.000 & 0.000 & -0.000 & 0.000 & $-0.001^{*}$ & 0.001 & 0.000 & 0.001 \\
Remittance & 0.000 & 0.000 & $0.000^{* * *}$ & 0.000 & -0.000 & 0.000 & 0.000 & 0.000 \\
SexHH & 0.167 & 0.238 & $1.749^{* *}$ & 0.867 & $5.146^{* * *}$ & 1.702 & 0.100 & 0.203 \\
TLU & $0.149^{* *}$ & 0.063 & $0.188^{* *}$ & 0.095 & $0.208^{* * *}$ & 0.077 & -0.013 & 0.056 \\
Treatment & $-0.536^{*}$ & 0.302 & -0.097 & 0.521 & $-0.967^{* *}$ & 0.394 & 0.168 & 0.268 \\
cons & -0.010 & 0.671 & -5.860 & 1.725 & -5.526 & 0.870 & -0.238 & 0.616 \\
\hline /atrho21 & 0.075 & 0.148 & & & & & & \\
/atrho31 & $1.211^{* * *}$ & 0.171 & & & & & & \\
/atrho41 & 0.073 & 0.098 & & & & & & \\
/atrho32 & 0.246 & 0.186 & & & & & & \\
/atrho42 & -0.186 & 0.132 & & & & & & \\
/atrho43 & 0.002 & 0.110 & & & & & & \\
\hline
\end{tabular}

Note: $* * *, * *$ and $*$ indicate statistical significance at $1 \%, 5 \%$ and at $10 \%$, respectively

Source: Computed from own survey data (2019)

Table 5. Estimated marginal effect of technology adoption

\begin{tabular}{|c|c|c|c|c|c|c|c|c|}
\hline \multirow[t]{2}{*}{ Variables } & \multicolumn{2}{|c|}{$\begin{array}{l}\text { Irrigation } \\
\text { practice }\end{array}$} & \multicolumn{2}{|c|}{$\begin{array}{c}\text { Adoption modern } \\
\text { beehive }\end{array}$} & \multicolumn{2}{|c|}{$\begin{array}{l}\text { Adoption of } \\
\text { generator }\end{array}$} & \multicolumn{2}{|c|}{$\begin{array}{l}\text { Adoption of tef } \\
\text { row sawing }\end{array}$} \\
\hline & $d y / x x$ & Std. Err. & dy/xx & Std. Err. & dy/xx & Std. Err. & $d y / x x$ & Std. Err \\
\hline AccessCrdt & -0.025 & 0.257 & 0.192 & 0.327 & 0.063 & 0.313 & $0.505 * *$ & 0.236 \\
\hline AccessEx & 0.189 & 0.194 & 0.335 & 0.307 & $0.537 * *$ & 0.234 & -0.236 & 0.196 \\
\hline AgeHH & $-0.062 * * *$ & 0.022 & 0.062 & 0.041 & -0.056 & 0.054 & $-0.033^{*}$ & 0.018 \\
\hline EDHH & -0.009 & 0.030 & $0.065^{*}$ & 0.035 & 0.015 & 0.035 & -0.005 & 0.026 \\
\hline Farmingyear & $0.059 * * *$ & 0.022 & -0.053 & 0.039 & 0.053 & 0.052 & $0.041 * *$ & 0.017 \\
\hline Fsize & $0.109 * *$ & 0.049 & 0.128 & 0.087 & 0.047 & 0.059 & -0.004 & 0.048 \\
\hline lsize & 0.190 & 0.363 & -0.786 & 0.534 & 0.363 & 0.416 & -0.226 & 0.334 \\
\hline MarketDis & -0.062 & 0.060 & -0.053 & 0.108 & -0.107 & 0.077 & 0.042 & 0.056 \\
\hline Nfarmincome & -0.000 & 0.000 & -0.000 & 0.000 & $-0.001 *$ & 0.000 & 0.000 & 0.000 \\
\hline Remittance & 0.001 & 0.000 & $0.001 * * *$ & 0.000 & -0.000 & 0.000 & 0.000 & 0.000 \\
\hline SexHH & 0.167 & 0.238 & $0.749 * *$ & 0.867 & $0.146 * * *$ & 0.702 & 0.100 & 0.203 \\
\hline TLU & $0.149 * *$ & 0.063 & $0.188^{* *}$ & 0.095 & $0.208 * * *$ & 0.077 & -0.011 & 0.058 \\
\hline Treatment & $-0.537 *$ & 0.302 & -0.097 & 0.521 & $-0.969 * *$ & 0.394 & 0.168 & 0.268 \\
\hline
\end{tabular}

Note: $* * *, * *$ and $*$ indicate statistical significance at $1 \%, 5 \%$ and at $10 \%$, respectively

Source: Computed from own survey data (2019) 


\section{CONCLUSIONS}

This study explores the effect of urban expansion on agricultural technology adoption of smallholder peri-urban farmers. The model reveals that being displaced has a negative statistically significant effect on households' participation in irrigation and generator adoption. Surprisingly, being displaced has a negative statistically insignificant effect on modern beehive adoption and a positive statistically insignificant effect on tef row sawing. Hence, the result confirms that urban expansion decreases the tendency of agricultural technology adoption among displaced smallholder peri-urban farmers. Therefore, the Bureau of Agriculture and other policymakers should devise a mechanism to avert the negative ramification of urban expansion on smallholder peri-urban farmers. Besides, adequate training and monitoring system should be provided to enhance agricultural technology adoption of smallholder peri-urban farmers.

\section{ACKNOWLEDGEMENT}

We are grateful to the board of editorial committee of Caraka Tani: Journal of Sustainable Agriculture for your invaluable comments, and Aksum University and Addis Ababa University for their partial funding to data collection only.

\section{REFERENCES}

Abdullahi, H. S., Mahieddine, F., Sheriff, R. E. (2015). Technology impact on agricultural productivity: A review of precision agriculture using unmanned aerial vehicles. In: Pillai P., $\mathrm{Hu}$ Y., Otung I., Giambene G. (eds) Wireless and Satellite Systems. WiSATS 2015. Lecture Notes of the Institute for Computer Sciences, Social Informatics and Telecommunications Engineering, 154, 388-400. https://doi.org/ 10.1007/978-3-319-25479-1_29

Abebe, W., Puskur, R., \& Karippai, R. S. (2008). Adopting improved box hive in Atsbi Wemberta district of Eastern Zone, Tigray Region: Determinants and financial benefits. Addis Ababa, Ethiopia: International Livestock Research Institute. 30 pp. Retrieved from https://cgspace.cgiar.org/bitstream/hand le/10568/475/BoxHive_IPMSWP10.pdf.pdf?s equence $=2 \&$ is Allowed $=y$

Adeoti, A. I. (2009). Factors influencing irrigation technology adoption and its impact on household poverty in Ghana. Journal of Agriculture and Rural Development in the Tropics and Subtropics, 109(1), 51-63. Retrieved from https://www.jarts.info/index. php/jarts/article/view/73

Admassie, A., \& Ayele, G. (2010). Adoption of improved technology in Ethiopia. Ethiopian Journal of Economics, 19(1), 155-180. https:// doi.org/10.4314/eje.v19i1.71416

Bekuma, A. (2018). Review on adoption of modern beehive technology and determinant factors in Ethiopia. Journal of Natural Sciences Research, 8(3), 26-29. Retrieved from https://www.iiste.org/Journals/index.php /JNSR/article/view/41219

Arslan, A., Floress, K., Lamanna, C., Lipper, L., Asfaw, S., \& Rosenstock, T. (2020). IFAD research series 63 - The adoption of improved agricultural technologies: A meta-analysis for Africa (2020). Rome, Italy: International Fund for Agricultural Development (IFAD). Retrieved from https://ssrn.com/abstract=379 5242

Awotide, B. A., Karimov, A. A., \& Diagne, A. (2016). Agricultural technology adoption, commercialization and smallholder rice farmers' welfare in rural Nigeria. Agricultural and Food Economics, 4(1), 1-24. https:// doi.org/10.1186/s40100-016-0047-8

Boserup, E., \& Chambers, R. (1965). The conditions of agricultural growth: The economics of agrarian change under population pressure (1st ed.). London: Routledge. https://doi.org/10.4324/97813150 70360

Chemwok, C. K., Tuitoek, D. K., \& Nganai, S. K. (2016). Factors influencing honey production in Marigat, Baringo County Kenya. International Journal of Research and Innovation in Social Science (IJRISS), 3(2), 426-434. Retrieved from https://www. rsisinternational.org/journals/ijriss/Digital-Lib rary/volume-3-issue-2/426-434.pdf

Chochran, W. G. (1977). Sampling techniques (3rd ed). New York: John Wiley and Sons. Inc. Retrieved from https://glad.geog.umd.edu/ Potapov/_Library/Cochran_1977_Sampling Techniques_Third_Edition.pdf 
Christiaensen, L., De Weerdt, J., \& Todo, Y. (2013). Urbanization and poverty reduction: The role of rural diversification and secondary towns. Agricultural Economics, 44(4-5), 435447. https://doi.org/10.1111/agec.12028

Chuchird, R., Sasaki, N., \& Abe, I. (2017). Influencing factors of the adoption of agricultural irrigation technologies and the economic returns: A case study in Chaiyaphum Province, Thailand. Sustainability, 9(9), 1524. https://doi.org/ 10.3390/su9091524

CIMMYT Economics Program, International Maize, \& Wheat Improvement Center. (1993). The adoption of agricultural technology: A guide for survey design. Mexico, D.F.: CIMMYT. Retrieved from https://repository.cimmyt.org/bitstream/handl e/10883/895/42412.pdf?sequence=1\&isAllow ed $=\mathrm{y}$

Creswell, J. W., Plano Clark, V. L., Gutmann, M., \& Hanson, W. (2003). Advanced mixed methods research designs. In Tashakkori, A., \& Teddle, C. (Eds.), Handbook of mixed methods in social and behavioral research (pp. 209-240). Thousand Oaks, CA: Sage. Retrieved from https://scholar.google.co.id/ scholar?cluster $=9762952061206456817 \& \mathrm{hl}=\mathrm{i}$ $\mathrm{d} \&$ as_sdt $=2005 \&$ sciodt $=0,5 \&$ authuser $=3$

de Janvry, A., Macours K., \& Sadoulet, E. (2017). Learning for adopting: Technology adoption in developing country agriculture. ClermontFerrand, France: Ferdi. Retrieved from https: //ferdi.fr/en/publications/learning-for-adoptin g-technology-adoption-in-developing-country -agriculture

Deksisa, K., \& Bayissa, M. (2020). Determinants of small-scale irrigation use: The case of Jeldu District, West Shewa Zone, Oromia National Regional State, Ethiopia. Journal of Agricultural Economics and Rural Development, 6(1), 705-711. Retrieved from https://www.premierpublishers.org/articles/04 1120195335

Egidi, G., Halbac-Cotoara-Zamfir, R., Cividino, S., Quaranta, G., Salvati, L., \& Colantoni, A. (2020). Rural in town: Traditional agriculture, population trends and long-term urban expansion in metropolitan Rome. Land, 9(2), 53. https://doi.org/10.3390/land9020053
Feola, G., Suzunaga, J., Soler, J., \& Wilson, A. (2020). Peri-urban agriculture as quiet sustainability: Challenging the urban development discourse in Sogamoso, Colombia. Journal of Rural Studies, 80, 1-12. https://doi.org/10.1016/j.jrurstud.2020.04.032

Fetenssa, G. D. (2018). Determinants of adoption of improved box hive in Gambella Zuria District, southwest Ethiopia. [Master thesis]. Jimma, Ethiopia: Jimma University.

Getacher, T., Mesfin, A., \& Gebre-Egziabher, G. (2013). Adoption and impacts of an irrigation technology: Evidence from household level data in Tigray, Northern Ethiopia. African Journal of Agricultural Research, 8(38), 4766-4772. Retrieved from https://academic journals.org/journal/AJAR/article-full-text-pd f/60EDBB435698

Gill, G. (2002). Applications of appropriate agricultural technology and practices and their impact on food security and the eradication of Poverty: Lessons learned from selected community based experiences. London: Overseas Development Institute. Retrieved from https://cdn.odi.org/media/docu ments/1902.pdf

Gwan, A. S., \& Kimengsi, J. N. (2020). Urban expansion and the dynamics of farmers' livelihoods: Evidence from Bamenda, Cameroon. Sustainability, 12(14), 5788. https://doi.org/10.3390/su12145788

Happy, F. A., Begum, I. A., \& Dhar, A. R. (2019). Impact of remittance on agricultural technology adoption and employment generation in Lakshmipur District of Bangladesh. American Journal of Agricultural and Biological Sciences, 14(1), 16-22. https:// doi.org/10.3844/ajabssp.2019.16.22

Hosseinifarhangi, M., Turvani, M. E., van der Valk, A., \& Carsjens, G. J. (2019). Technology-driven transition in urban food production practices: A case study of Shanghai. Sustainability, 11(21), 6070. https:// doi.org/10.3390/su11216070

Jebesa, S. R. (2017). Assessment of factors affecting adoption of modern beehive in East Wolega Zone, Western Oromia. International Journal of Engineering Research \& Technology, 6(1), 85-91. 
Retrieved from https://www.ijert.org/assess ment-of-factors-affecting-adoption-of-modern -beehive-in-east-wolega-zone-western-oromia

Langemeyer, J., Madrid-Lopez, C., Mendoza Beltran, A., \& Villalba Mendez, G. (2021). Urban agriculture - A necessary pathway towards urban resilience and global sustainability? Landscape and Urban Planning, 210, 104055. https://doi.org/ 10.1016/j.landurbplan.2021.104055

Li, H., Huang, D., Ma, Q., Qi, W., \& Li, H. (2020). Factors influencing the technology adoption behaviours of litchi farmers in China. Sustainability, 12(1), 271. https://doi. org/10.3390/su12010271

Meinzen-dick, R., Adato, M., Haddad, L., \& Hazell, P. (2004). Food policy report, science and poverty: An interdisciplinary assessment of the impact of agricultural research. Washington, D.C.: International Food Policy Research Institute (IFPRI). Retrieved from https://ispc.cgiar.org/sites/default/files/pdf/10 4.pdf

Mekonnen, T. (2009). Impact of agricultural technology adoption on market participation in the rural social network system, Working Paper Series. Boschstraat Maastricht, Netherlands: UNU-MERIT. Retrieved from https://www.merit.unu.edu/publications/worki ng-papers/abstract/?id=6353

Melisse, B. (2018). A review on factors affecting adoption of agricultural new technologies in Ethiopia. Journal of Agricultural Science and Food Research, $9(3), 226$. Retrieved from https://www. longdom.org/open-access/a-review-on-factors -affecting-adoption-of-agricultural-new-techn ologiesin-ethiopia.pdf

Mengistu, T. (2016). Horizontal urban expansion and livelihood adjustment problem among ex-farmers in the Kebeles surrounding Jimma Town: The case of Derba Kebele. European Scientific Journal, 12(14), 308-328. https://doi.org/10.19044/esj.2016.v12n14p308

Muzari, W., Gatsi, W., \& Muvhunzi, S. (2012). The impacts of technology adoption on smallholder agricultural productivity in Sub-Saharan Africa: A review. Journal of Sustainable Development, 5(8), 69-77. https:// doi.org/10.5539/jsd.v5n8p69

National Metrological Agency of Ethiopia [NMAE]. (2019). Unpublished report.

Regassa, A. E. (2016). Determinants of agro pastoralists participation in irrigation scheme: The case of fentalle agro Pastoral District, Oromia Regional State, Ethiopia. International Journal of Agricultural Research, Innovation and Technology, 5(2), 44-50. https://doi.org/10.3329/ijarit.v5i2.262 69

Rustiadi, E., Pravitasari, A. E., Setiawan, Y., Mulya, S. P., Pribadi, D. O., \& Tsutsumida, N. (2021). Impact of continuous Jakarta megacity urban expansion on the formation of the Jakarta-Bandung conurbation over the rice farm regions. Cities, 111, 103000. https://doi.org/10.1016/j.cities.2020.103000

Sharaunga, S., \& Mudhara, M. (2018). Determinants of farmers' participation in collective maintenance of irrigation infrastructure in KwaZulu-Natal. Physics and Chemistry of the Earth, Parts $A / B / C$, 105, 265-273. https://doi.org/10.1016/j.pce. 2018.02.014

Sisay, G. (2018). Determinants of female-headed households' participation in periurban modern small-scale irrigation projects in Ethiopia: The case of Kobo Town. Irrigation and Drainage, 67(5), 670-683. https://doi.org/ 10.1002/ird.2283

Tamirat, N. (2020). Impact analysis of row planting teff crop technology on household welfare: A case study of smallholder farmers of Duna District in Hadiya Zone, Ethiopia. Journal of Economics and Sustainable Development, 11(5), 4-9. https://doi.org/ 10.7176/JESD/11-5-02

Tiffen, M. (2003). Transition in Sub-Saharan Africa: Agriculture, urbanization and income growth. World Development, 31(8), 1343 1366. https://doi.org/10.1016/S0305-750X(0 3)00088-3

Uchida, E., Rozelle, S., \& Xu, J. (2009). Conservation payments, liquidity constraints and off-farm labor: Impact of the grain-forgreen program on rural households in China. American Journal of Agricultural Economics, 91(1), 70-86. https://doi.org/10.1111/j.1467- 


\subsubsection{4.x}

United Nations Development Programme. (2015). Sustainable development goals booklet. New York: United Nations Development Programme. Retrieved from https://www. undp.org/publications/sustainable-developme nt-goals-booklet

Urgessa, Fekadu, B., \& Chaneyalew, S. (2020). Factors affecting smallholder farmers participation and level of participation in small scale irrigation: The case of Deder District of Eastern Hararghe Zone, Ethiopia. International Journal of Advance Research Agriculture \& Agribusiness, 8(3), 695-705. http://dx.doi.org/10.21474/IJAR01/10681

Weldearegay, S. K., Tefera, M. M., \& Feleke, S. T. (2021). Impact of urban expansion to peri- urban smallholder farmers' poverty in Tigray, North Ethiopia. Heliyon, 7(6), e07303. https:// doi.org/10.1016/j.heliyon.2021.e07303

Woreda Office of Agriculture and Rural Development [WOARD]. (2019). Unpublished report.

World Bank. (2008). World development report 2008: Agriculture for development. Washington, D.C.: IBRD/World Bank Retrieved from https://www.ilo.org/public/ libdoc/igo/P/03632/03632(2008).pdf

Young, G., Valdez, E. A., \& Kohn, R. (2009). Multivariate probit models for conditional claim-types. Insurance: Mathematics and Economics, 44(2), 214-228. https://doi.org/ 10.1016/j.insmatheco.2008.11.004 